\title{
Effects of Tapinanthus Globiferus Leaf Extract on Blood Glucose and Pancreatic Histology in Alloxanized and Normoglycemic Rats
}

\author{
D.O. Edem ${ }^{1}$, I.A. Edagha ${ }^{2}$, B.B. Ette ${ }^{3}$, P.E. Agwuigwo ${ }^{1}$ \\ ${ }^{1}$ Department of Biochemistry, University of Uyo, P.M.B. 1017, Uyo, Akwa Ibom State, Nigeria. \\ ${ }^{2}$ Department of Anatomy, University of Uyo, P.M.B. 1017, Uyo, Akwa Ibom State, Nigeria. \\ ${ }^{3}$ Department of Biochemistry, Akwa Ibom State Polytechnic, Ikot Osurua - Ikot Ekpene, Nigeria. \\ *Corresponding Author: David Okon Edem, Department of Biochemistry, University of Uyo, P.M.B. 1017, Uyo, \\ Akwa Ibom State, Nigeria.
}

Abstract

Consumption of herbal medicines in diabetes management is on the increase. The study aimed at investigating effects of ethanol leaf extracts of Tapinanthus globiferus (Family: Loranthaceae) on blood glucose and pancreatic histology in diabetic and normoglycemic rats. Rats were assigned into 7 groups of 5 rats each. Two groups of rats, viz. normal control and diabetic control, did not receive any extract. Test groups were made diabetic with intra-peritoneal injection of alloxan. Two (2) diabetic test groups were administered with 450 and $900 \mathrm{mg} / \mathrm{kg}$ body weight ( $\mathrm{bw}$ ) of T. globiferus leaf extract, as was also done for 2 normoglycemic test groups. A third diabetic test group was administered with standard antidiabetic metformin $(7.14 \mathrm{mg} / \mathrm{kg} \mathrm{bw})$. After 14 days, concentrations of blood glucose and histological features were examined in all experimental groups. In diabetic rats given extracts and metformin, blood glucose levels were significantly reduced $(p<0.05)$ by 68.29 $83.47 \%$ of initial values; while in normoglycemic rats extracts depreciated glucose concentrations by 19.05 to $21.23 \%$. Histological studies demonstrated amelioration of degenerative effects on pancreatic islets of diabetic animals, in addition to distortions of pancreatic architecture in normoglycemic animals by high dose extracts. The results suggested glucose-lowering action of extracts, through alterations of pancreatic islet structure / function. Short-term administration of T. globiferus leaves may contribute significantly to normalization of blood glucose by pancreatotrophic effects and can be useful in management of diabetes.

Keywords: Tapinanthus globiferus, mistletoe, leaf, antihyperglycemic, hypoglycemic, pancreatotrophic.

\section{INTRODUCTION}

Diabetes mellitus (DM) is a metabolic disorder of the endocrine system. Diabetes is defined as an intricate chronic illness resulting from defect in insulin secretion, insulin action, or both and thereby leading to hyperglycemia [1]. Hyperglycemia, mainly caused by insulin resistance, affects the metabolism of lipids, carbohydrates and proteins in addition to increasing oxidative stress by enzymatic and non-enzymatic processes [2-7]. When the total antioxidant capacity of the body is exceeded, such that the free radical scavenging ability of the antioxidant system is reduced, complications from DM arise. The non-communicable disease affects all systems in the body, leading to severe and irreversible pathological conditions such as nephropathy, retinopathy, vasculopathy, neuropathy and cardiovascular diseases, as well as hepatopathy ${ }^{[8]}$.

Diabetes mellitus (DM) is a major public health problem worldwide, affecting about 415 million people and set to escalate to 642 million by the year 2040 [9-14].

For now, the present management of diabetes is aimed at achieving normoglycemia, in order to prevent later microvascular complications (such as retinopathy and nephropathy among others) ${ }^{15}$.

Currently available therapeutic options for DM, such as oral antihyperglycemics and insulin, have limitations of their own [16-21]. 
Effects of Tapinanthus Globiferus Leaf Extract on Blood Glucose and Pancreatic Histology in Alloxanized and Normoglycemic Rats

The undesirable side effects of synthetic drugs, and the fact that they are not suitable for use during pregnancy, have been some of the factors leading to the strong desire to use antihyperglycemic agents of plant origin. The search for appropriate antihyperglycemic / hypoglycemic agents has been focused on plants used in traditional medicine [22-31]. Plants may act on blood glucose through different mechanisms. They may: (a) stimulate pancreatic islet $\beta$-cell release of insulin, (b) inhibit hormones that increase blood glucose, (c) increase the number, affinity, or sensitivity of the insulin receptor to insulin, (d) decrease the release of glycogen, (e) enhance the use of glucose in tissues and organs, (f) clear away free radicals, resist lipid peroxidation and correct the lipid / protein metabolic disorder and (g) improve microcirculation in the body [25, 32 -37].

In spite of the fact that only a few of the antidiabetic herbal remedies have received scientific scrutiny, mistletoe plants have been reported to be used in folkloric medicine in diabetes management, with efficacy depending on the host plant of origin [38].

Apreviousreport[39] demonstratedantihyperglycemic effects of leaf extracts of Tapinanthus globiferus (a mistletoe plant) on diabetic rats. Some plant extracts have been reported to possess significant blood sugar lowering activity in diabetic animals, but without hypoglycemic action in non-diabetic animals [40]. To the best of our knowledge, there is not a systematic study on the hypoglycemic effect of T. globiferus on normoglycemic rats. The aim of this study was to investigate the blood sugar lowering activity of leaf extract of Tapinanthus globiferus and its possible role on pancreatic tissue of both diabetic and normoglycemic rats.

\section{Materials AND MethodS}

\section{Animals}

This experiment was carried out in the Faculty of Basic Medical Sciences, University of Uyo, Nigeria, between the months of September and November 2019.

Thirty five (35) male Wistar albino rats weighing 180 - 200g were obtained from the Animal House of the Department of Biochemistry, University of Calabar, Nigeria. The rats were kept in clean and dry plastic cages, with $12 \mathrm{hrs}$ light-dark cycle at $25 \pm 2^{\circ} \mathrm{C}$ and 45 $55 \%$ relative humidity. The animals were fed with

pelletized commercial rat mash (Bendel Feed and Flour Mill Ltd, Benin, Nigeria) and tap water ad libitum, throughout the duration of the experiment. The rats were assigned into 7 groups of 5 rats each. Ethical Approval was obtained from the Ethical Committee of the Faculty of Basic Medical Sciences of University of Uyo, Nigeria, and the experimental procedures were carried out in accordance with the "Principles of Laboratory Animal care" of National Institutes of Health (NIH) publication number 85-23 as revised in 1985. All animals were treated in accordance with the NIH Guide for the Care and Use of Laboratory Animals [41].

\section{Sample Collection}

Samples of Tapinanthus globiferus leaves were obtained from Itak Ikot Akap village in Ikono Local Government Area of Akwa Ibom State in Nigeria. They were collected from the host guava tree (Psidium guajava) in the month of September 2019. The plant material was authenticated by a taxonomist Professor (Mrs.) M.E. Bassey of the Department of Botany and Ecological Studies, University of Uyo, Nigeria. A voucher specimen with number 'Edem UUH 1963 (Ikono)' was deposited in the herbarium of the University of Uyo. The samples were washed with clean tap water to remove dirt on the leaves. After the leaves were kept for $2 \mathrm{hrs}$ for the water to dry off, a sharp stainless steel knife was used to cut them into small pieces. They were then dried to constant weight in an oven (Stuart Scientific, UK) at $55^{\circ} \mathrm{C}$ for 24 hours. After drying, the leaves were ground into fine powder (which passed through a 30-mesh sieve) and stored in air containers at $4{ }^{\circ} \mathrm{C}$ until when required.

\section{Preparation of Ethanol Extract of T. globiferus leaves}

One hundred grams $(100 \mathrm{~g})$ of the ground leaf was soaked in $500 \mathrm{~mL}$ of $80 \%$ ethanol for $24 \mathrm{hrs}$ for complete extraction (i.e. solvent: leaf ratio was 5:1). The mixture was stirred using a stirring rod and allowed to stand, after which there was filtration (using cheesecloth) into a beaker. One hundred milliliter (100 $\mathrm{mL}$ ) aliquots of the extract were poured into separate beakers of known weight. The solutions were dried at $50^{\circ} \mathrm{C}$ to constant weight using a rotary evaporator. The extract concentration was determined by gravimetric method. Five grams $(5 \mathrm{~g})$ of the extract was dissolved in $100 \mathrm{~mL}$ of distilled water. Thus the concentration of 
Effects of Tapinanthus Globiferus Leaf Extract on Blood Glucose and Pancreatic Histology in Alloxanized and Normoglycemic Rats

the extract was $50 \mathrm{mg} / \mathrm{mL}$ and $1.80 \mathrm{ml}$ of the solution administered to $205 \mathrm{~g}$ rat was equivalent to $450 \mathrm{mg} /$ $\mathrm{kg}$ body weight. Other doses per weight of rats were determined accordingly.

\section{Animal Treatments}

The 7 group of rats were as follows: Diabetic group 1 (DG-450), Diabetic group 2 (DG-900), Diabetic control (DC), Non-diabetic group 1 (NDG-450), Non- diabetic group 2 (NDG-900), Diabetic group administered standard antidiabetic drug metformin (DG-MTS) and Normal control (NC). DG-450, DG-900, DG-MTS and DC groups were made hyperglycemic by intra - peritoneal injection of $150 \mathrm{mg} / \mathrm{kg}$ body weight (bw) of alloxan monohydrate (Sigma) dissolved in sterile distilled water. The NC and NDG groups were not treated with alloxan. Diabetes was confirmed 3 days after alloxan injection by determining the blood glucose concentration using One Touch Basic Glucometer. Then groups DG-450 and NDG-450 were administered with $450 \mathrm{mg} / \mathrm{kg}$ bw of the extract, while groups DG-900 and NDG-900 were administered with $900 \mathrm{mg} / \mathrm{kg}$ bw of the extract. Group DG-MTS was administered with $7.14 \mathrm{mg} / \mathrm{kg}$ bw metformin standard antidiabetic drug. All drug and extract administration was performed by oral gavage for 14 days. Groups DC and NC, which served as treatment controls, were gavaged with distilled water.

\section{Collection and Treatment of Samples}

After 14 days, the animals were anaesthetized with chloroform. Blood samples were obtained by cardiac punctureand transferredintosterilesamplecontainers. Blood was allowed to clot at room temperature for one hour. It was then centrifuged for 10 minutes at a speed of $3000 \mathrm{rpm}$ to harvest the serum. Serum was separated and stored in plain sterile bottles at $-20^{\circ} \mathrm{C}$ until used for analysis of blood glucose.

\section{Blood Glucose Analysis}

Blood glucose concentration was estimated by glucose oxidase method [42], using a reagent kit from Randox Laboratory Ltd, UK.

\section{Histopathological Study}

On the last day of experiment, the tail parts of the pancreas were removed and kept in 10\% neutral buffered formalin for a minimum of 72 hours. Tissue processing was carried out using graded series of alcohol, for examination under the light microscope in accordance with the method described by Cardiff et al. [43]. Stained sections were morphologically evaluated.

\section{Statistical Analysis}

All data were expressed as means \pm SD. Student's $t$ - test was used to compare the mean values of test groups and control. Differences in mean values were considered significant at $\mathrm{p}<0.05$.

\section{RESULTS}

\section{Blood Glucose Concentrations}

The results indicating the effects of leaf extracts on blood glucose concentrations of experimental rats are presented in Table 1 . Treatment with $150 \mathrm{mg} / \mathrm{kg}$ bw alloxan after 3 days caused significant increases $(\mathrm{p}<0.05)$ in blood glucose levels of rats $(\mathrm{mmol} / \mathrm{L})$ in groups DC (16.40), DG-450 (18.10), DG-900 (25.44) and DG-MTS (21.60), compared with NC and NDG groups (3.72-3.80).

Table 1. Hypoglycemic Effects of Ethanolic Extract of Tapinanthus globiferus Leaves*

\begin{tabular}{|l|c|c|c|c|c|c|c|}
\hline \multirow{2}{*}{$\begin{array}{l}\text { Plasma Glucose } \\
\text { Concentrations }\end{array}$} & NC & DC & DG-450 & DG-900 & NDG-450 & NDG-900 & DG-MTS \\
\cline { 2 - 8 } & $3.80 \pm 0.09$ & $16.40 \pm 0.92$ & $18.10 \pm 2.45$ & $25.44 \pm 7.20$ & $3.78 \pm 3.06$ & $3.72 \pm 0.23$ & $21.60 \pm 8.53$ \\
\hline Initial (mmol/L) & $4.28 \pm 0.62^{\mathrm{a}}$ & $25.40 \pm 4.71^{\mathrm{b}}$ & $5.74 \pm 2.29^{\mathrm{a}}$ & $5.61 \pm 1.96^{\mathrm{a}}$ & $3.06 \pm 0.44^{\mathrm{c}}$ & $2.93 \pm 0.26^{\mathrm{c}}$ & $3.57 \pm 0.64^{\mathrm{ac}}$ \\
\hline Final (mmol/L) & +12.63 & +54.88 & -68.29 & -77.95 & -19.05 & -21.23 & -83.47 \\
\hline$\%$ change & & &
\end{tabular}

*Values are means \pm standard deviation $(n=5)$. Values in same row with different superscripts in a horizontal row represent means that are significantly different $(\mathrm{p}<0.05)$. 
Effects of Tapinanthus Globiferus Leaf Extract on Blood Glucose and Pancreatic Histology in Alloxanized and Normoglycemic Rats

\section{Legend}

$\mathrm{NC}=$ Normal Control; $\mathrm{DC}=$ Diabetic Control,

DG-450 = Diabetic Group administered with $450 \mathrm{mg} / \mathrm{kg}$ body weight (bw) extract of T. globiferus leaf

DG-900 = Diabetic Group administered with $900 \mathrm{mg} / \mathrm{kg}$ bw extract of T. globiferus leaf,

NDG-450 = Non-diabetic Group administered with 450mg/ kg bw extract of T. globiferus leaf

NDG-900 = Non-diabetic Group administered with 900mg/ kg bw extract of T. globiferus leaf

DG-MTS = Diabetic Group administered with $7.14 \mathrm{mg} / \mathrm{kg}$ bw metformin standard antidiabetic drug.

In diabetic (or hyperglycemic) rats, blood glucose levels were significantly reduced $(\mathrm{p}<0.05)$ on consumption of T. globiferus leaf extracts (by $68.29-74.84 \%$ ) and metformin (by $83.47 \%$ ). The antihyperglycemic efficacy in DG-900 rats (74.84\%) was comparable with that of metformin. No significant differences in blood glucose were observed between diabetic groups which received $450 \mathrm{mg} / \mathrm{kg}$ bw $(5.74 \mathrm{mmol} / \mathrm{L})$ and $900 \mathrm{mg} / \mathrm{kg}$ bw extract $(5.61 \mathrm{mmol} / \mathrm{L})(\mathrm{p}>0.05)$. The initial levels of blood glucose in the normoglycemic groups, viz. NDG-450 and NDG-900 (3.72 - 3.78 mmol/L) were reduced after extract consumption (by $19.05-21.23 \%)$.

After the experimental period, the blood glucose concentrations in NC and DC groups were $4.28 \mathrm{mmol} / \mathrm{L}$ and $25.40 \mathrm{mmol} / \mathrm{L}$ respectively. In comparison with
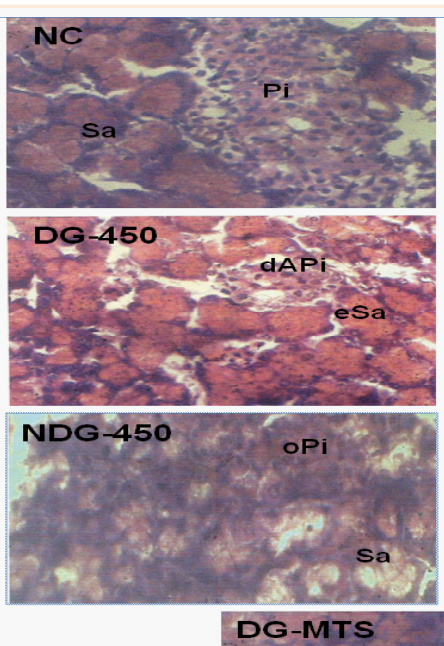

the DC group, the other experimental groups had significantly lower mean blood glucose of $2.93-5.74$ $\mathrm{mmol} / \mathrm{L}(\mathrm{p}<0.05)$. The normoglycemic groups (NDG) had significantly lower glucose concentrations $(2.93$ - $3.06 \mathrm{mmol} / \mathrm{L})$ when compared with the $\mathrm{NC}(\mathrm{p}<$ 0.05).

\section{Effects of Consumed Extracts on Histopathology of Pancreas: Histomorphologic Changes of Pancreas}

The cellular integrity and architecture were intact in the NC group (Fig.1 NC). Pancreatic sections stained with hematoxylin and eosin (H \& E) showed that alloxan caused severe necrotic changes of pancreatic islets, especially in the centre of islets. Nuclear changes, karyolysis, disappearance of nucleus and in some places, residue of destroyed cells were visible. Relative reduction of size and number of islets especially around the central vessel and severe reduction of beta cells were clearly seen (Fig. 1 DC). Study of pancreas of treated diabetic groups (DG-450 and DG-900) showed increased size of islets and hyperchromic nucleus in sections stained with $\mathrm{H} \& \mathrm{E}$. These was also a relative increase of granulated and normal beta cells in the diabetic group which consumed $900 \mathrm{mg} / \mathrm{kg}$ bw extract, when compared with the diabetic group which consumed $450 \mathrm{mg} / \mathrm{kg}$ bw extract (Fig. 1[DG450 \& DG-900]). Pancreas of the non-diabetic group which consumed $450 \mathrm{mg} / \mathrm{kg}$ bw

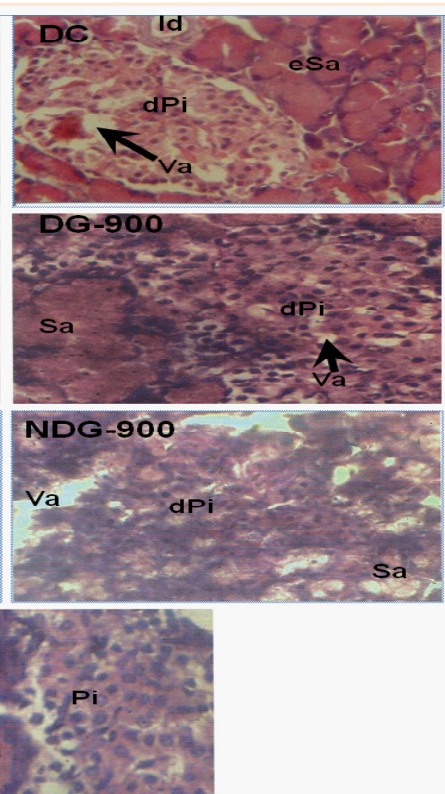

Figure 1. Photomicrograph of transverse section of the pancreas H\&E stained at x400 
Effects of Tapinanthus Globiferus Leaf Extract on Blood Glucose and Pancreatic Histology in Alloxanized and Normoglycemic Rats

$\mathrm{NC}=$ Normal control (appears normal); DC = Diabetic control (severely affected)

$\mathrm{DG}_{450}=$ Diabetic group treated with $T$. globiferus $450 \mathrm{mg} / \mathrm{kg}$ bw (moderately affected)

$\mathrm{DG}_{900}=$ Diabetic group treated with T. globiferus $900 \mathrm{mg} / \mathrm{kg}$ bw (moderately affected)

$\mathrm{NDG}_{450}=$ Non-diabetic group administered T. globiferus 450 $\mathrm{mg} / \mathrm{kg}$ bw (moderately affected)

$\mathrm{NDG}_{900}=$ Non-diabetic group administered T. globiferus 900 $\mathrm{mg} / \mathrm{kg}$ bw (severely affected)

DG-MTS = Diabetic group treated with standard anti-diabetic drug Metformin 7.14mg/kg bw Legend: Va = Vacuolation, $\mathrm{Sa}=$ Serous acini; $\mathrm{eSa}=$ Esinophilic Serous acini; oPi = obscured Pancreatic islets; $\mathrm{dPi}=$ degenerating and distorted Pancreatic islets; Id = Intralobular duct.

extract (Fig. 1 NDG-450), showed some similarity to that of NDG-900, which consumed $900 \mathrm{mg} / \mathrm{kg}$ bw extract (Fig. 1 NDG-900). However, there was more severe degeneration and distortion of pancreatic islets in the NDG-900 than in NDG-450 group. Pancreas of the DG-MTS (Fig. 1 DG- MTS) showed increased size of islets and nucleus, similar to observation in diabetic rats treated with the extracts.

\section{Discussion}

The initial blood glucose of 16.40 - $25.44 \mathrm{mmol} / \mathrm{L}$ (for the diabetic groups) was considered hyperglycemic for the experiment $[44,45]$. There were significant reductions $(p<0.05)$ in blood glucose levels for the test groups (DG-450, DG-900 and DG- MTS) and the normoglycemic groups that received extracts. The results suggest both hypoglycemic and antihyperglycemic effects of the T. globiferus leaf extracts. The glucose-lowering activity exhibited by these extracts could be due to the ability of the extracts to inhibit endogenous glucose production, inhibit insulinase activity, or increase insulin production from the $\beta$ cells of pancreas [30].

The findings are indicative of the presence of some hypoglycemic agents in the leaves of T. globiferus, which could have been concentrated in the extracts. The hypoglycemic effects of plants might be due to the presence of insulin-like substances in plants [34, 46], stimulation of $\beta$ cells to produce more insulin $[47,48]$, or regenerative effect of plants on pancreatic tissue $^{[32] \text {. }}$
The pancreatic $\beta$ cells were destroyed by alloxan, which has a destructive effect on the beta cells of the pancreas [29]. The pancreas senses the organism's dietary and energetic states via glucose concentration in the blood. In response to elevated blood glucose, it secretes insulin. The cytotoxic action of alloxan (a glucose analogue) on pancreatic beta cells leads to the development of hyperglycemia by inhibiting glucokinase, and generating free radicals which leads to increased oxidative stress in addition to depleting plasma antioxidants $[49,50]$. Expression of antioxidant enzymes is very low in islet cells compared with other tissues and cells [51]. Once beta cells are challenged by oxidative stress they may remain sensitive to the toxicity of hyperglycemia. Thus the blood glucose of the untreated diabetic group (DC) was expected to increase instead of reducing, while the diabetic groups that were treated with T. globiferus leaf extract achieved good glycemic control.

Histopathological study of diabetic untreated (DC) rats showed degeneration of pancreatic islet cells, which was due to alloxan used in this study. This probably gave rise to insulin deficiency. The results in diabetic-treated groups (DGs) indicated increase in pancreatic islets after consumption of extracts or standard antidiabetic metformin, which may be signs of regeneration. Signs of regeneration of $B$ cells, potentiation of insulin secretion from surviving $B$ cells of the islets of Langerhans and decrease of blood glucose have been reported following consumption of some plant extracts [30, 32, 52-54]. Tapinanthus globiferus leaf may have some chemical components that exert regenerative effects on $B$ cells, stimulate these cells to produce more insulin (pancreatotrophic action) or may have some insulin-like substances. A higher dose of the extract had a greater restorative effect on the islet cells of diabetic rats than a lower dose of extract. However, there were distortions in the pancreatic islet architecture of normoglycemic rats which consumed high dose extracts. The antihyperglycemic efficacy (relative glucose-lowering ability) of the ethanol leaf extract of T. globiferus in alloxanized rats was between 81.81 and $89.66 \%$ of that of metformin.

Metformin, abiguanide marketed under the trade name Glucophage $\AA$ among others, is the first line commonly used antidiabetic drug [55]. It suppresses hepatic glucose production, increases insulin sensitivity, 
Effects of Tapinanthus Globiferus Leaf Extract on Blood Glucose and Pancreatic Histology in Alloxanized and Normoglycemic Rats

enhances glucose uptake by phosphorylating GLUTenhancer factor, increases fatty acid oxidation, decreases the absorption of glucose from the gastrointestinal tract $[15,56]$, in addition to activating AMP-activated protein kinase, (an enzyme that plays a role in the expression of hepatic gluconeogenic genes) $[57,58]$. It has a lower incidence of hypoglycemia when compared to sulfonylureas, like glibenclamide $[16,17,19,20]$ : In our study, the normoglycemic rats that were given leaf extracts had final blood glucose concentrations (mmol/L) ranging from 2.93 (NDG$450)$ to 3.07 (NDG-900), while metformin-treated rats had $3.57 \mathrm{mmol} / \mathrm{L}$. These values could not be considered to be cases of hypoglycemia [59], bearing in mind the reference values of 2.65 to $5.94 \mathrm{mmol} / \mathrm{L}$ for rats [44].

Thus, in view of the fact that the extracts exhibited efficacy comparable to that of metformin, the plant T. globiferus has a high potential of being used in the management of diabetes mellitus.

\section{CONCLUSION}

The findings of this study indicate that consumption of the ethanol extract of T. globiferus leaf exerts significant antihyperglycemic effect in diabetic rats. The extract moderately protects pancreatic islets from diabetes - induced distortions. The blood glucose lowering potential of the extract at high doses over a long period of time could produce hypoglycemia in normoglycemic rats, leading to moderate or severe distortion of pancreatic islets. Though this study supports the traditional use of $T$. globiferus for controlling hyperglycemia in diabetics, it is advised that prolonged usage be discouraged once normoglycemia is achieved.

\section{REFERENCES}

[1] American Diabetes Association [ADA]. Standards of medical care in diabetes - 2014. Diabetes Care. 2014; 37(Supplement1): S14- S80. https://doi. org/10.2337/dc14-S014.

[2] Feillet-Coudray C, Rock E, Coudray C, Grzelkowska K, Azais- Braesco V, Dardevet D, Mazur A. Lipid peroxidation and antioxidant status in experimental diabetes. Clin. Chem. Acta. 1999; 284(1): 31-43. https://doi.org/10.1016/S00098981(99)00046-7

[3] Ceriello A, Motz E. Is oxidative stress the pathogenic mechanism underlying insulin resistance, diabetes, and cardiovascular disease? The common soil hypothesis revisited. Arterioscler. Thromb. Vasc. Biol. 2004; 24(5): 816-823. https://doi.org/10.1161/01. ATV.0000122852.22604.78.

[4] Rolo AP, Palmeira CM. Diabetes and mitochondrial function: role of hyperglycemia and oxidative stress. Toxicol. Appl. Pharmacol. 2006; 212(2):167-178. DOI:10.1016/j. taap.2006.01.003.

[5] Palsamy P, Sivakumar S, Subramanian S. Resveratrol attenuates hyperglycemia-mediated oxidative stress, proinflammatory cytokines and protects hepatocytes ultrastructure in streptozotocin-nicotinamide-induced experimental diabetic rats. Chem. Biol. Interact. 2010; 186: 200-210. DOI: 10.1016/j. cbi.2010.03.028.

[6] Olooto WE., Ogundahunsi OA, Banjo TA, Salau BA, Amballi AA, Ajani EO, Onakomaya OA. Hypoglycemic and modifying effect of aqueous cocoa powder extract on diabetic-induced histologic changes in the pancreas of alloxan diabetic rats. Annals of Biological Sciences. 2014; 2 (1):10-18. https://www.researchgate.net/ publication/273322266_Hypoglycemic_and_ modifying_effect_of_aqueous_cocoa_powder_ extract_on_diabetic-

[7] Mohamed J, Nazratun Nafizah AH, Zariyantey AH, Budin SB. Mechanisms of diabetes-induced liver damage: The role of oxidative stress and inflammation. Sultan Qaboos University Med. J. 2016; 16(2):132-141. DOI: 10.18295/ squmj.2016.16.02.002

[8] Reid AE. Non-alcoholic fatty liver disease. In: Feldman M, Friedman LS, Brandt LJ (editors), Sleisenger and Fordtran's Gastrointestinal and liver disease: pathophysiology/diagnosis/ management. 8th ed., St Louis, Missouri, USA: Saunders. 2006; pp. 1772-1799.

[9] Burke JP, Williams K, Venkat Naryan KM, Leibson C, Haffner SM, Stern MP. A population perspective on diabetes prevention: Whom should we target for preventing weight gain? Diabetes Care. 2003; 26: 1994-2004. https://doi.org/10.2337/ diacare.26.7.1999. 
Effects of Tapinanthus Globiferus Leaf Extract on Blood Glucose and Pancreatic Histology in Alloxanized and Normoglycemic Rats

[10] Sy GY, Cisse A, Nongonierma RB, Saw M, Mbodj NA, Faye B. Hypoglycaemic and antidiabetic activity of acetonic extract of Vernonia colorata leaves in normoglycaemic and alloxan-induced diabetic rats. J. Ethnopharm. 2005; 98: 171-175. DOI: $10.1016 /$ j.jep.2005.01.024.

[11] Osinubi AAA · Effects of Vernonia amygdalina and chlorpropamide on blood glucose. Medical Journal of Islamic World Academy of Sciences. 2007; 16 (3): 115-119. https://www.journalagent.com/ ias/pdfs/IAS_16_3_115_119.pdf.

[12] Danaei G, Finucane MM, Lu Y, Singh GM, Cowan MJ, Paciorek CJ, Lin JK, Farzadfar F, Khang YH, Stevens GA, Rao M, Ali MK, Riley LM, Robinson CA, Ezzati M.. National, regional, and global trends in fasting plasma glucose and diabetes prevalence since 1980: systematic analysis of health examination surveys and epidemiological studies with 370 country-years and 2.7 million participants. Lancet. 2011; 378(9785): 31-40. DOI: 10.1016/S0140-736(11)60679-X.

[13] Al-Lawati JA. Diabetes mellitus: A local and global public health emergency! Oman Medical Journal. 2017; 329(3): 177-179. DOI: 10.5001/ omj.2017.34.

[14] International Diabetes Federation. IDF Diabetes Atlas, $7^{\text {th }}$ Edition, 2017; Available from: http:// www. diabetesatlas.org/.

[15] Olokoba AB, Obateru OA, Olokoba LB. Type 2 diabetes mellitus: A review of current trends. Oman Medical Journal. 2012; 27(4): 269-273. DOI: $10.5001 /$ omj.2012.68.

[16] Shorr RI, Ray WA, Daugherty JR, Griffin MR. Individual sulfonylureas and serious hypoglycemia in older people. J. Am. Geriatr. Soc. 1996; 44(7):751- 755. https://doi.org/10.1111/ j.1532-5415.1996.tb03729.x

[17] Staa TV, Abenhaim L, Monette J. Rates of hypoglycemia in users of sulfonylureas. J. Clin. Epidemiol. 1997; 50(6):735-741. https://doi. org/10.1016/S0895-4356(97)00024-3.

[18] Raz I, Chen Y, Wu M, Hussain S, Kaufman KD, Amatruda JM, Langdon RB, Stein PP, Alba M.
Efficacy and safety of sitagliptin added to ongoing metformin therapy in patients with type 2 diabetes. Curr. Med. Res. Opin. 2008; 24(2):537550. DOI: $10.1185 / 030079908 X 260925$.

[19] Chiniwala N, Jabbour S. Management of diabetes mellitus in the elderly. Curr. Opin. Endocrinol. Diabetes Obes. 2011; 18(2):148-152. DOI: 10.1097/MED.0b013e3283444ba0.

[20] Balsells M, García-Patterson A, Solà I, Roqué M, Gich I, Corcoy R. Glibenclamide, metformin, and insulin for the treatment of gestational diabetes: a systematic review and meta-analysis. British Medical Journal. 2015; 350: h102 - 113. DOI: 10.1136/bmj.h102.

[21] Nachum Z, Zafran N, Salim R, Hissin N, Hasanein J, Gam Ze Letova Y, Suleiman A, Yefet E. Glyburide versus metformin and their combination for the treatment of gestational diabetes mellitus: A randomized controlled study. Diabetes Care. 2017; 40(3):332-337. DOI: $10.2337 / \mathrm{dc} 16-$ 2307.

[22] Berger W. Incidence of severe side effects during therapy with sulphonylureas and biguanides. Hormones Metabolic Res. 1985; 17: 111-115. https://www.ncbi.nlm.nih.gov/ pubmed/3865878.

[23] Rates SM. Plants are source of drugs. Toxicology, 2001; 39(5): 603-631. https://www.ncbi. nlm.nih.gov/pubmed/11072038https://doi. org/10.1016/S0041-0101(00)00154-9.

[24] Elder C. Ayurveda for diabetes mellitus. A review of the biochemical literature. Altern. Ther. Health Med. 2004; 10: 44 - 50. https://www.ncbi.nlm. nih.gov/pubmed/14727499.

[25] Li WL, Zheng HC, Bukuru J, De Kimpe N. Natural medicines used in the traditional Chinese medical system for therapy of diabetes mellitus. J. Ethnopharm. 2004; 92(1): 1 -21. DOI: 10.1016/j. jep.2003.12.031.

[26] Srinvasan K. Plant foods in the management of diabetes mellitus: Spices as beneficial antidiabetic food adjuncts. Int. J. Food Sci. Nutr. 2005; 56: 399 - 414. doi: 10.1080/09637480500512872. 
Effects of Tapinanthus Globiferus Leaf Extract on Blood Glucose and Pancreatic Histology in Alloxanized and Normoglycemic Rats

[27] Badole S, Patel N, Bodhankar S, Jain B, Bhardwaj S. Antihyperglycemic activity of aqueous extract of leaves of Cocculus hirsutus (L.) Diels in alloxaninduced diabetic mice. Indian J. Pharmacol. 2006; 38: 49-53. http://www.ijp-online.com/text. asp?2006/38/1/49/19853.

[28] Jung M, Park M, Lee HC, Kang Y, Kang ES, Kim SK. Antidiabetic agents from medicinal plants. Current Medicinal Chemistry. 2006; 13:12031218. DOI : $10.2174 / 092986706776360860$.

[29] Jelodar G, Mohsen M, Shahram S. Effect of walnut leaf, coriander and pomegranate on blood glucose and histopathology of pancreas of alloxan - induced diabetic rats. African J. Traditional, Complementary and Alternative Medicines (Afr. J. Trad. CAM). 2007; 4 (3): 299-305. https://www. ncbi.nlm.nih.gov/pmc/articles/PMC2816491/ pdf/AJT0403-0299.pdf.

[30] Yadav JP, Saini S, Kalia AN, Dangi AS. Hypoglycemic activity of ethanolic extract of Salvadora oleoides in normal and alloxan-induced diabetes rats Indian J. Pharmacology. 2008; 40 (1): 23 - 27. DOI: $10.4103 / 0253-7613.40485$.

[31] Eliakim-Ikechukwu CF, Edem AA, William UM, OkoriSO, Ihentuge CJ. Phytochemical composition of Cassia alata leaf extract and its effect on the histology of the pancreas of diabetic Wistar rats. IOSR Journal of Pharmacy and Biological Sciences. 2013; 5(5):07-13. https://pdfs.semanticscholar. org/d717/38714caf1c43aeb0f9af44e50eb5222 e631a.pdf.

[32] Shanmugasundaram ER, Gopith KI, Radha SK, Rajendram VM. Possible regeneration of the islets of Langerhans in streptozotocin-diabetic rats given Gymnema sylvestere leaf extracts. J. Ethnopharm. 1990; 30: 265-269. https://doi. org/10.1016/0378-8741(90)90106-4.

[33] Bolkent S, Yanardağ R, Tabakoğlu-Oğuz A, ÖzsoySaçan Ö. Effect of chard (Beta vulgaris L. var. cicla) extract on pancreatic beta cells in streptozotocindiabetic rats. A morphological and biochemical study. Journal of Ethnopharmacology. 2000; 73(1-2): 251-259. https://doi.org/10.1016/ S0378-8741(00)00328-7.
[34] Gray AM, Flatt PR. Insulin-releasing and insulinlike activity of the traditional antidiabetic plant Coriander sativum (coriander). Br. J. Nutr. 1999; 81: 203-208. https://doi.org/10.1017/ S0007114599000392.

[35] Cho SY, Park JY, Park EM, Choi MJ, Lee MK, Jeon SM, Jang MK, Kim MJ, Park YB. Alternation of hepatic antioxidant enzyme activities and lipid profile in streptozotocin-induced diabetic rats by supplementation of dandelion water extract. Clinica Chimica Acta. 2002; 317(12):109-117. https://doi.org/10.1016/S00098981(01)00762-8.

[36] Eddouks M, Jouad H, Maghrani M, Lemhadri A, Burcelin R. Inhibition of endogenous glucose production accounts for hypoglycemic effect of Spergularia purpurea in streptozotocin mice. Phytomedicine: International Journal of Phytotherapy and Phytopharmacology. 2003; 10 (6-7): 594-599. DOI: 10.1078/094471103322331890.

[37] Mooradian AD. Antioxidants and diabetes. Nestle Nutrition Workshop Series. Clinical and performance program. 2006; 11:107-122.

[38] Adesina SK, Illoh HC, Johnny II, Jacobs IE. African mistletoes (Loranthaceae); ethnopharmacology, chemistry and medicinal values: An update. Afr. J. Tradit. Complement. Altern. Med. 2013; 10(3):161-170. http://dx.doi.org/10.4314/ ajtcam.v10i4.26. 161.

[39] Ogbonnia SO, Anyika EN, Mbaka GO, Utah P, Ugwu D, Nwakakwa N, Ota DA. Antihyperglycaemic and antihyperlipidaemic effects of aqueous ethanol extract of Tapinanthus globiferus leaves and Treculia africana root bark and their mixture on alloxan diabetic rats. Agric. Biol. J. N. Am., 2012; 3(6): 237-246. DOI:10.5251/ abjna.2012.3.6.237.246.

[40] Özbek H, Ceylan E, Kara M, Özgökce F, Koyuncu M. Hypoglycemic effect of Rheum ribes roots in alloxan induced diabetic and normal mice. Scand. J. Lab. Anim. Sci. 2004; 31: 113-115. https:// www.scribd.com/document/19643929/ Hypoglycemic-Effect-of-Rheum-Ribes-Roots-inAlloxan-Induced. 
Effects of Tapinanthus Globiferus Leaf Extract on Blood Glucose and Pancreatic Histology in Alloxanized and Normoglycemic Rats

[41] NRC. National Research Council Guide for the care and use of laboratory animals. 1985; Publication no. 85 - 23 (Rev.). National Institutes of Health, Bethesda, MD.

[42] Barham D, Trinder P. An improved color reagent for the determination of blood glucose by the oxidase system. Analyst. 1972; 97 (151):142 - 145. https://www.ncbi.nlm.nih.gov/ pubmed/5037807.

[43] Cardiff RD, Miller CH, Munn RJ. Manual hematoxylin and eosin staining of mouse tissue sections. Cold Spring Harbor Protocols. 2014; 2014(6): 655-658.

DOI: $10.1101 /$ pdb.prot073411.

[44] Kaneko JJ, Harvey JW, Bruss ML. Clinical Biochemistry of domestic animals. $5^{\text {th }}$ edn., New York, Academic Press. 1997; pp. 895-899.

[45] Cox EM, Edelman D. Test for screening and diagnosis of type 2 diabetes. Clin. Diabetes. 2009; 4(27):132-138. DOI: 10.2337/diaclin.27.4.132.

[46] Collier E, Watkinson A, Cleland CF, Roth J. Partial purification and characterization of an insulinlike material from spinach and lemna gibba G3. J. Biol. Chem. 1987; 262: 6238 - 6241. http://www. jbc.org/content/262/13/6238.long.

[47] Chang MW, Johnson MA. Effect of garlic on carbohydrate metabolism and lipid synthesis in rats. J. Nutr. 1980; 110: 931-936. DOI: 10.1093/ jn/110.5.931.

[48] Khan A, Bryden NA, Polasky MN, Anderson RA. Insulin-potentiating factor and chromium content of selected spices. Biol. Trace Elem. Res. 1990; 24(2-3):183-188. https://doi.org/10.1007/ BF02917206.

[49] Shabeer J, Srivastava RS, Sing SK. Antidiabetic and antioxidant effect of various fractions of Phyllanthus simplex in alloxan diabetic rats. Journal of Ethnopharmacology. 2009; 124: 3438. DOI: $10.1016 / j$.jep.2009.04.015.

[50] Dhanesha N, Joharapurkur A, Ashah G, Dhote V, Kshirsagar S, Bahekar R, Jain M. Extendin-4 ameliorates diabetic syndrome through activation of glucokinase. Journal of Diabetes. 2012; 4(4): 369-377. DOI: 10.1111/j.17530407.2012.00193.x.

[51] Tiedge M, Lortz S, Drinkgern J, Lenzen S. Relation between antioxidant enzyme gene expression and antioxidative defense status of insulin producing cells. Diabetes. 1997; 46: 1733-1742. https://doi.org/10.2337/diab.46.11.1733.

[52] Aybar MJ, Sánchez Riera AN, Grau A, Sánchez SS. Hypoglycemic effect of the water extract of Smallanthus soncifolius (Yacon) leaves in normal and diabetic rats. J. Ethnopharmacol. 2001; 74: 125-132. https://doi.org/10.1016/ S0378-8741(00)00351-2. DOI: 10.4103/02537613.19853 .

[53] Suba V, Muragesan T, Bhaskara Rao R, Ghosh L, Pal M, Mandal SC, Saha BP. Antidiabetic potential of Barleria lupulina extract in rats. Fitoterapia. 2004; 75(1):1-4. https://doi.org/10.1016/ S0367-326X(03)00163-1; DOI:10.1016/j. fitote.2004.02.00

[54] Subash-Babu P, Ignacimuthu S, Agastian P, Varghese B: Partial regeneration of $\beta$-cells in the islets of Langerhans by Nymphayol: a sterol isolated from Nymphaea stellata (Willd.) flowers. Bio-organic and Medicinal Chemistry. 2009; 17 (7):2864-2870. DOI: 10.1016/j. bmc.2009.02.021.

[55] Fischer J. Analogue-based Drug Discovery II. John Wiley \& Sons. 2010; pp. 47 49. ISBN 9783527632121.

[56] Kamenova P, Atanasova I, Kirilov G. Metformin Improves Insulin Secretion and Reduces Insulin Resistance in People at High Risk for Development of Type 2 Diabetes Mellitus and Cardiovascular Disease. Merit Research Journal of Medicine and Medical Sciences. 2016; 4(3):152-161. http://www.meritresearchjournals.org/mms/ content/2016/March/Kamenova\%20et\%20al. pdf.

[57] Collier CA, Bruce CR, Smith AC, Lopaschuk G, Dyck DJ. Metformin counters the insulininduced suppression of fatty acid oxidation and stimulation of triacylglycerol storage in rodents skeletal muscle. Am. J. Physiol. Endocrinol. Metab. 2006; 219(1):182-189. DOI: 10.1152/ ajpendo.00272.2005. 
Effects of Tapinanthus Globiferus Leaf Extract on Blood Glucose and Pancreatic Histology in Alloxanized and Normoglycemic Rats

[58] Kim YD, Park KG, Lee YS, Park YY, Kim DK, [59] Amiel SA, Dixon T, Mann R, Jameson K. Nedumaran B, Jang WG, Cho WJ, Ha J, Lee IK, Lee $\mathrm{CH}$, Choi HS. Metformin inhibits hepatic gluconeogenesis through AMP-activated protein Hypoglycemia in type 2 diabetes. Diabet Med. 2008; 25(3):245-254. DOI: 10.1111/j.14645491.2007.02341.x. kinase-dependent regulation of the orphan nuclear receptor SHP. Diabetes. 2008; 57(2):

306-314. DOI: 10.2337/db07-0381.

Citation: D.o. Edem, I.A. Edagha et al. Effects of Tapinanthus Globiferus Leaf Extract on Blood Glucose and Pancreatic Histology in Alloxanized and Normoglycemic Rats. Archives of Diabetes and Endocrine System. 2020; 3(2): 01-10.

Copyright: (C) 2020 D.0. Edem, I.A. Edagha et al. This is an open access article distributed under the Creative Commons Attribution License, which permits unrestricted use, distribution, and reproduction in any medium, provided the original work is properly cited. 